\title{
Azo Dye Adsorption onto Cobalt Oxide: Isotherm, Kinetics, and Error Analysis Studies
}

\author{
Hawraa Kassem Hami, Ruba Fahmi Abbas*, Shireen Abdulmohsin Azeez, and Nedaa Ibrahim Mahdi \\ Department of Chemistry, College of Science, Mustansiriyah University, Baghdad, Iraq
}

\author{
* Corresponding author: \\ email: rubaf1983@uomustansiriyah.edu.iq
}

Received: December 17, 2020

Accepted: June 10, 2021

DOI: $10.22146 /$ ijc. 62326

\begin{abstract}
The current study focused on utilizing cobalt oxide to eliminate hazardous Eriochrome Black $T$ (EBT) dye. The impact of $p H(2,4,7,8$, and 10) and temperature $\left(45,50\right.$, and $\left.55^{\circ} \mathrm{C}\right)$ was examined for $E B T$ removal. The results show that the maximum sorption occurred at $\mathrm{pH}=2$ and that the removal percentage increased with increasing temperature. Five non-linear regression methods were used to predict the best isotherm and kinetic models. A coefficient of nondetermination, $K^{2}$, was very helpful for selecting the RMSD function as a preferable error function among the five methods. Isothermal models to illustrate equilibrium sorption information, the Langmuir, Freundlich, Temkin, and DubininRadushkevich models were used. The results showed that the Langmuir model $\left(R^{2}\right.$ $=0.99$ ) was the most favorable, indicating monolayer sorption of EBT occurred. The kinetics models were analyzed using pseudo-first-order and pseudo-secondorder whereas the sorption information was well described by the pseudo-secondorder model $\left(R^{2}=0.99\right)$. The results of the thermodynamic study appeared that the adsorption of EBT was endothermic, feasible, spontaneous, and physical adsorption.
\end{abstract}

Keywords: Eriochrome Black T dye; adsorption; isotherm; kinetic; error analysis

\section{- INTRODUCTION}

Dyes are very recalcitrant compounds as they are stable to light, temperature, and microbial attack. Dyes are used in many vital industries and classified as one of the major causes of pollution of water resources [1]. Azo dyes are environmentally polluting dyes that are carcinogenic and very difficult to degrade even at low concentrations. They are released in massive quantities directly into water bodies impacting aquatic life and the food web [2-3]. Azo dyes are categorized as one of the most hazardous dyes due to their extreme stability in the aquatic environment, complex aromatic structure, azoic linkages, amino groups, and toxic nature; all these factors combine to make azo dyes hazardous health of living organisms [4-5]. Eriochrome Black T (EBT) is an anionic form of azo dyes. This dye is commonly used as a metallochromic indicator and employed in dyeing silk, nylon, and wool. EBT is a toxic compound whose breakdown can make a phenolic substance carcinogen [67]. This dye is not degraded by biological treatment and is resistant to decomposition under aerobic digestion and oxidation agents because it consists of azo groups ($\mathrm{N}=\mathrm{N}-$ ) with aromatic rings and sulfonate groups [8-9]. EBT is a poison dye that causes blindness, severe eye and skin irritation, liver damage, loss of consciousness, and coma [10]. Numerous chemical, physical, and biological processes have been developed to remove dyes from water, including chemical oxidation, flotation, ion exchange, and electrochemical treatments [11-12]. Nonetheless, adsorption stands out among these approaches due to its speed. Many adsorbents are used to remove EBT dye like Cotton Waste [13], surfactant modified clay [8], Nteje Clay [2], and metal oxide [1112]. Besides simplicity, economics, and effectiveness, reusability of adsorbent is possible. This fact made adsorption proven to be the preferable method for wastewater treatment [14-15]. Metal oxide adsorbent is low cost and efficient for the adsorption process. Metal oxides are widely used due to their ease of obtaining, limited solubility, amphoteric properties, oscillator properties, cheapness, and impedance to thermal decomposition compared to other surfaces [16-17]. 
Several metal oxides such as iron(III) oxide $\left(\mathrm{Fe}_{2} \mathrm{O}_{3}\right)$, zirconium oxide $\left(\mathrm{ZrO}_{2}\right)$, aluminum(III) oxide $\left(\mathrm{Al}_{2} \mathrm{O}_{3}\right)$, and cobalt oxide $\left(\mathrm{Co}_{3} \mathrm{O}_{4}\right)$ have been used for this purpose [18]. In this report, EBT dye was removed $\mathrm{Co}_{3} \mathrm{O}_{4}$ as a low cost and effective adsorbent. The impacts of some parameters like $\mathrm{pH}$ and temperature were studied. Four adsorption isotherms were used to find the optimum isotherm, in addition to the analyze and discuss kinematic and thermodynamic data to use $\mathrm{Co}_{3} \mathrm{O}_{4}$ as an effective and low-cost adsorbent for EBT removal. Errol statistics were used to assess the adequacy and quality of the fitted models.

\section{- EXPERIMENTAL SECTION}

\section{Materials}

Eriochrome Black T(BDH), $\mathrm{Co}_{3} \mathrm{O}_{4}, \mathrm{HCl}$, and $\mathrm{NaOH}$ were purchased from $(\mathrm{BDH})$, the standard dye solution of $500 \mathrm{mg} \mathrm{L}^{-1}$ was prepared and used to make different concentrations using distilled water.

\section{Instrumentation}

The UV-Visible scanning spectrum was taken on a (Cary 100, VARIAN CO.). A centrifuge, shaking water bath (BS-11 digital, JETO Korea, TECH) was used to shake off the samples. The $\mathrm{pH}$ meter (Hana) was used to measure the $\mathrm{pH}$ of solutions.

\section{Procedure}

\section{Adsorption experiments}

Batch experiments were conducted under optimal conditions, with a $50 \mathrm{~mL}$ flask containing $10 \mathrm{~mL}$ of EBT solution $\left(50 \mathrm{mg} \mathrm{L}^{-1}\right), 0.1 \mathrm{~g}$ of $\mathrm{Co}_{3} \mathrm{O}_{4}$ adsorbent, $\mathrm{pH} 2$, and $55{ }^{\circ} \mathrm{C}$. The flask was set on a shaking water bath and shaking at $500 \mathrm{rpm}$ for $50 \mathrm{~min}$. The $\mathrm{pH}$ of EBT solution was adjusted by $0.1 \mathrm{M}$ hydrochloric acid and sodium hydroxide in the range $(2,4,7,8$, and 10). Three temperatures $\left(45,50\right.$, and $\left.55^{\circ}\right)$ were used to study the impact of temperature. Adsorption isotherms are evaluated at different concentrations $\left(30,40,50\right.$, and $\left.60 \mathrm{mg} \mathrm{L}^{-1}\right)$, while kinetic studies are done at various mixing times $(10,20,30$, $40,50$, and $60 \mathrm{~min})$. Then the EBT was separated from the stained solution by centrifuging for $15 \mathrm{~min}$ (3000 rpm), and the concentration of the dye was determined at $\lambda_{\max }=$ $520 \mathrm{~nm}$. The following equation is used to calculate the adsorption capacity and color removal (\%):
$\mathrm{q}_{\mathrm{e}}=\mathrm{C}_{0}-\mathrm{C}_{\mathrm{e}} \times \frac{\mathrm{v}}{\mathrm{m}}$

Removal \% $=\frac{\mathrm{C}_{0}-\mathrm{C}_{\mathrm{e}}}{\mathrm{C}_{0}} \times 100$

where $\mathrm{v}(\mathrm{L})$ is the volume of dye solution, $\mathrm{m}(\mathrm{mg})$ is the mass of $\mathrm{Co}_{3} \mathrm{O}_{4}, \mathrm{C}_{0}$ and $\mathrm{C}_{\mathrm{e}}\left(\mathrm{mg} \mathrm{L}^{-1}\right)$ are $\mathrm{EBT}$ initial and equilibrium concentration, respectively [19].

\section{Isotherm and kinetic studies}

Isotherm studies were used to analyzed data and estimate the applicability of the process. The Langmuir, Freundlich, Temkin, and Dubinin-Radushkevich models were employed to describe the adsorption system. For further interpretations in favor of adsorption, a separation factor $\left(R_{L}\right)$ was used as in Eq. (3)

$\mathrm{R}_{\mathrm{L}}=\frac{1}{1+\mathrm{K}_{\mathrm{L}} \mathrm{C}_{0}}$

where $K_{L}(L / m g)$ is the Langmuir constant. $R_{L}$ implies the kind of isotherm to be irreversible $\left(R_{L}=0\right)$, favorable $\left(0<\mathrm{R}_{\mathrm{L}}<1\right)$, linear $\left(\mathrm{R}_{\mathrm{L}}=1\right)$ or unfavorable $\left(\mathrm{R}_{\mathrm{L}}>1\right)$ [14].

Also, Dubinin-Radushkevich isotherm was used to identify if the adsorption is physic sorption or chemisorption from its mean (E) $\mathrm{kJ} \mathrm{mol}^{-1}$, which supply's beneficial information on the type of mechanism of the adsorption system. (E) can defend by: $\mathrm{E}=\frac{1}{\sqrt{-2 \beta}}$

If the quantity of (E) less than $8 \mathrm{~kJ} \mathrm{~mol}^{-1}$, the reaction became is physical adsorption. While, if (E) value between ( 8 to 16 ) $\mathrm{kJ} \mathrm{mol}^{-1}$, the adsorption process is via ion exchange mechanism, and If $(\mathrm{E})>16 \mathrm{~kJ} \mathrm{~mol}^{-1}$, the mechanism of particle diffusion and the reaction is chemisorptions [20-21].

Kinetics was verified by examining the impact of contact time to remove the EBT dye using the pseudofirst-order and pseudo-second-order models. The most appropriate model chosen is based on $\mathrm{R}^{2}$ and error functions for both isotherm and kinetic studies. Table 1 included all equations that were used in this study.

\section{Error analysis}

Error analysis is an essential parameter that assessments how well the curve pronounces the experimental data. It is not sufficient to analyze the data 
based on the $\mathrm{R}^{2}$ value to select the suitable isotherm and kinetic model, since to the empirical results $\mathrm{R}^{2}$ value can be high. Therefore, it is essential to diagnose regression to analyze the outcomes [22-23]. Five error functions were studied to find the most appropriate isotherm and kinetic model, as seen in Table 2.

\section{- RESULTS AND DISCUSSION}

\section{Effect of Solution pH}

$\mathrm{pH}$ is an essential factor that impacts the charge of the adsorbent surface and the degree of ionization of the sorbates in the solution. Thus, the $\mathrm{pH}$ impacts the

Table 1. Linear expressions of isothermal and kinetic models

\begin{tabular}{|c|c|c|c|c|c|}
\hline Isotherm model & Equation & Linearized form & Plot & Parameters & Ref. \\
\hline Langmuir & $\mathrm{qe}=\mathrm{q}_{\mathrm{m}} \mathrm{K}_{\mathrm{L}} \mathrm{C}_{\mathrm{e}} /\left(1+\mathrm{K}_{\mathrm{L}} \mathrm{C}_{\mathrm{e}}\right)$ & $1 / \mathrm{q}_{\mathrm{e}}=\left(1 / \mathrm{K}_{\mathrm{L}} \mathrm{q}_{\mathrm{m}} \mathrm{C}_{\mathrm{e}}\right)+\left(1 / \mathrm{q}_{\mathrm{m}}\right)$ & $1 / \mathrm{q}_{\mathrm{e}}$ vs. $1 / \mathrm{C}_{\mathrm{e}}$ & $\begin{array}{l}\mathrm{q}_{\mathrm{m}}=(\text { intercept })^{-1} \\
\mathrm{~K}_{\mathrm{L}}=\text { intercept } / \text { slope }\end{array}$ & [19] \\
\hline Freundlich & $\mathrm{q}_{\mathrm{e}}=\mathrm{K}_{\mathrm{F}}\left(\mathrm{C}_{\mathrm{e}}\right)^{1 / \mathrm{n}}$ & $\ln \mathrm{q}_{\mathrm{e}}=\ln \mathrm{K}_{\mathrm{F}}+\mathrm{n}^{-1} \ln \mathrm{C}_{\mathrm{e}}$ & $\ln q_{e}$ vs. $\ln C_{e}$ & $\begin{array}{l}K_{F}=\exp (\text { intercept }) \\
1 / n=\text { slope }\end{array}$ & [19] \\
\hline Temkin & $\begin{array}{l}\mathrm{q}_{\mathrm{e}}=\mathrm{B} \ln \left(\mathrm{K}_{\mathrm{T}} \mathrm{C}_{\mathrm{e}}\right) \\
\text { were } \mathrm{B}=\mathrm{RT} / \mathrm{b}\end{array}$ & $\mathrm{q}_{\mathrm{e}}=\mathrm{B} \ln \mathrm{K}_{\mathrm{T}}+\mathrm{B} \ln \mathrm{C}_{\mathrm{e}}$ & qe vs. $\ln C e$ & $\begin{array}{l}\mathrm{B}=\text { slope } \\
\mathrm{K}_{\mathrm{T}}=\exp (\text { intercept } / \text { slope })\end{array}$ & {$[1]$} \\
\hline $\begin{array}{l}\text { Dubinin- } \\
\text { Radushkevich (D-R) }\end{array}$ & $\begin{array}{l}\mathrm{q}_{\mathrm{e}}=\mathrm{q}_{\operatorname{mexp}}\left(-\beta \varepsilon^{2}\right) \\
\text { were } \varepsilon=\mathrm{RT} \ln \left(1+\mathrm{C}_{\mathrm{e}}^{-1}\right)\end{array}$ & $\ln q_{e}=\ln q_{m}-\beta \varepsilon^{2}$ & $\ln \mathrm{q}_{\mathrm{e}} \mathrm{vs} . \varepsilon^{2}$ & $\begin{array}{l}\mathrm{qm}=\exp (\text { intercept }) \\
\beta=- \text { slope }\end{array}$ & [20] \\
\hline \multicolumn{6}{|l|}{ Kinetics model } \\
\hline Pseudo-first-order & $\mathrm{qt}=\mathrm{q}_{\mathrm{e}}\left[1-\exp \left(-\mathrm{k}_{1} \mathrm{t}\right)\right]$ & $\operatorname{Ln}(\mathrm{qe}-\mathrm{qt})=\ln \mathrm{q}_{\mathrm{e}}-\mathrm{k}_{\mathrm{l}} \mathrm{t}$ & $\ln \left(q_{e}-q_{t}\right)$ vs. $t$ & $\begin{aligned} \mathrm{q}_{\mathrm{e}} & =\exp (\text { intercept }) \\
\mathrm{k}_{1} & =-(\text { slope })\end{aligned}$ & [10] \\
\hline Pseudo-second-order & $\mathrm{qt}=\mathrm{k}_{2} \mathrm{q}^{2} \mathrm{e} /\left(1+\mathrm{q}_{\mathrm{e}} \mathrm{k}_{2} \mathrm{t}\right)$ & $\mathrm{t} / \mathrm{q}_{\mathrm{t}}=1 / \mathrm{k}_{2} \mathrm{q}_{\mathrm{e}}^{2}+1 / \mathrm{q}_{\mathrm{e}} \mathrm{t}$ & $\mathrm{t} / \mathrm{q}_{\mathrm{t}} \mathrm{vs.} \mathrm{t}$ & $\begin{array}{l}\mathrm{q}_{\mathrm{e}}=\text { slope }^{-1}, \mathrm{k}_{2}= \\
\left(\text { slope }^{2}\right) / \text { intercept }\end{array}$ & [10] \\
\hline
\end{tabular}

$\mathrm{q}_{\mathrm{e}}, \mathrm{q}_{\mathrm{m}}, \mathrm{q}_{\mathrm{t}}\left(\mathrm{mg} \mathrm{g}^{-1}\right)$ are the sorption capacity at equilibrium, saturated, and at time $\mathrm{t} ; \mathrm{n}$ is heterogeneity of site energies; $\mathrm{b}(\mathrm{J} / \mathrm{mol})$ is Temkin constant; $\mathrm{B}(\mathrm{J} / \mathrm{mol})$ is constant related to heat of adsorption; $\varepsilon\left(\mathrm{J} \mathrm{mol}^{-1}\right)$ is the Polanyi potential; $\beta\left(\mathrm{mol}^{2} / \mathrm{kJ}^{2}\right)$ is the D-R constant; $\mathrm{R}(8.314 \mathrm{~J} / \mathrm{K} \mathrm{mol})$ is the gas constant; $\mathrm{T}(\mathrm{K})$ is the temperature; $\mathrm{t}(\mathrm{min})$ is time; $\mathrm{K}_{\mathrm{F}}\left(\mathrm{mgg}^{-1}\right)$ and $\mathrm{K}_{\mathrm{T}}(\mathrm{L} / \mathrm{g})$ are Freundlich and Temkin constants; $\mathrm{K}_{1}\left(\mathrm{~min}^{-1}\right)$ and $\mathrm{K}_{2}\left(\mathrm{mg} \mathrm{g}^{-1}\right.$ $\left.\mathrm{min}^{-1}\right)$ are pseudo-first order and pseudo-second order rate constants

Table 2. Error functions list

\begin{tabular}{|c|c|c|}
\hline Error functions & Equations & Ref. \\
\hline Marquardt's is the percent standard deviation (MPSD) & $100 \sqrt{\frac{1}{n-p}} \sum\left(\frac{q_{\text {cal. }}-q_{\text {exp. }}}{q_{\text {cal. }}}\right)^{2}$ & [11] \\
\hline Sum of absolute errors (EABS) & $\sum_{\mathrm{i}=1}^{\mathrm{n}}\left|\mathrm{q}_{\mathrm{cal}}-\mathrm{q}_{\exp .}\right|$ & [11] \\
\hline Chi-square $\left(\mathrm{X}^{2}\right)$ & $\sum_{\mathrm{i}=1}^{\mathrm{n}} \frac{\left(\mathrm{q}_{\text {cal. }}-\mathrm{q}_{\text {exp. }}\right)^{2}}{\mathrm{q}_{\text {cal. }}}$ & [15] \\
\hline $\begin{array}{l}\text { Reduced chi-square } \\
\text { Error }\left(\mathrm{X}^{2} \text {-red }\right)\end{array}$ & $\frac{1}{n-p} \sum_{i=1}^{n} \frac{\left(q_{\text {cal. }}-q_{\text {exp. }}\right)^{2}}{q_{\text {cal. }}}$ & [22] \\
\hline Root means square error (RMSD) & $\sqrt{\frac{1}{\mathrm{n}-1}\left(\mathrm{q}_{\mathrm{cal} .}-\mathrm{q}_{\text {exp. }}\right)^{2}}$ & [23] \\
\hline
\end{tabular}

$\mathrm{q}_{\text {exp. }}$ and $\mathrm{q}_{\text {cal. }}$ are experiment and calculated EBT concentration, $\mathrm{p}$ is the number of parameters $(\mathrm{p}=2$ for Langmuir and Freundlich and $3=$ Temkin and D-R), $\mathrm{n}$ is the number of experimental data (4) 
structural stability and the color intensity of the dyes [24]. Fig. 1 shows that the highest removal ratio when the $\mathrm{pH}=$ 2 , while increasing $\mathrm{pH}$ up to 10 reducing the removal percentage. The EBT removal at $\mathrm{pH}=2$ was $96.6 \%$. This decrease in removal ratio with increasing $\mathrm{pH}$ is associated with an increase in the number of $\mathrm{OH}$ - groups in the dye that may compete with anionic ions. As a result, as the number of positively charged sites decreases, so does the removal ratio. The sites negatively charged on the surface of the adsorbent will not prefer the adsorption of dye ions because of the electrostatic repulsion of $\mathrm{OH}$ - groups. The sulfonic group on the EBT dye may also bind via the ion exchange $[18,25]$. These results are similar to previous studies for adsorption of EBT dye on other oxide surfaces such as $\mathrm{Fe}_{2} \mathrm{O}_{3}[11], \alpha-\mathrm{Al}(\mathrm{OH})_{3}$ [25], and nanosilica [26].

\section{Isotherm Studies}

Adsorption isotherm is described as the ratio between the adsorbed quantity and the remaining in solution at a constant temperature, and it gives the capacity of the adsorbent and the relationship between adsorbent and adsorbate at equilibrium; Isotherm equips fundamental physiochemical information for the valuation of the applicability of a sorption system as an operation unit $[24,27]$. For analyzing the mechanism of EBT sorption on the $\mathrm{Co}_{3} \mathrm{O}_{4}$ surface, four isotherm equations (Langmuir, Freundlich, Temkin, and D-R) were used (Table 3).

By comparing the values of $R^{2}$ and the error functions in Table 3, it was discovered that the Langmuir isotherm is the most appropriate model to describe the study of EBT adsorption onto $\mathrm{Co}_{3} \mathrm{O}_{4}$. Modeling the equilibrium data using a Langmuir isothermal gave the highest R-value and the lowest MSPD, EABS, $\mathrm{X}^{2}, \mathrm{X}^{2}$-red, and RMSD values. Fig. 2(a-d) depicts the experimental Langmuir, Freundlich, Temin, and D-R models.

(i) The adsorption of EBT on the surface of $\mathrm{Co}_{3} \mathrm{O}_{4}$ is homogenous with monolayer adsorption [28].

(ii) The value of $R_{L}$ between 0 and 1 represents favorable sorption. Also, this is consistent with the findings from Freundlich model $0<1 / \mathrm{n}<1$, which indicates favorable sorption of dye on the adsorbent surface [28].

(iii) Because the sorption energy B from the Temkin isotherm was positive, the adsorption is endothermic [29].

(iv) The $\mathrm{D}-\mathrm{H}$ model calculated the mean sorption energy (E) of $0.158 \mathrm{~kJ} \mathrm{~mol}^{-1}$ within the range of physical adsorption (less than $8 \mathrm{~kJ} \mathrm{~mol}^{-1}$ ).

(v) Base on error functions, the isothermal arrangement for the most suitable empirical data in this search was: Langmuir $>$ Freundlich $>$ Temkin $>\mathrm{D}-\mathrm{H}$.

To verify the error function that reduces the distribution of errors between the theoretical and experimental isotherms, the coefficient of nondetermination $\left(\mathrm{K}^{2}\right)$ was used, and it calculates from:

$$
\begin{aligned}
\mathrm{K}^{2} & =\frac{\text { Unexplained variance }}{\text { Total variance }} \\
& =1-\frac{\text { Unexplained variance }}{\text { Total variance }} \\
& =1-\mathrm{r} 2
\end{aligned}
$$
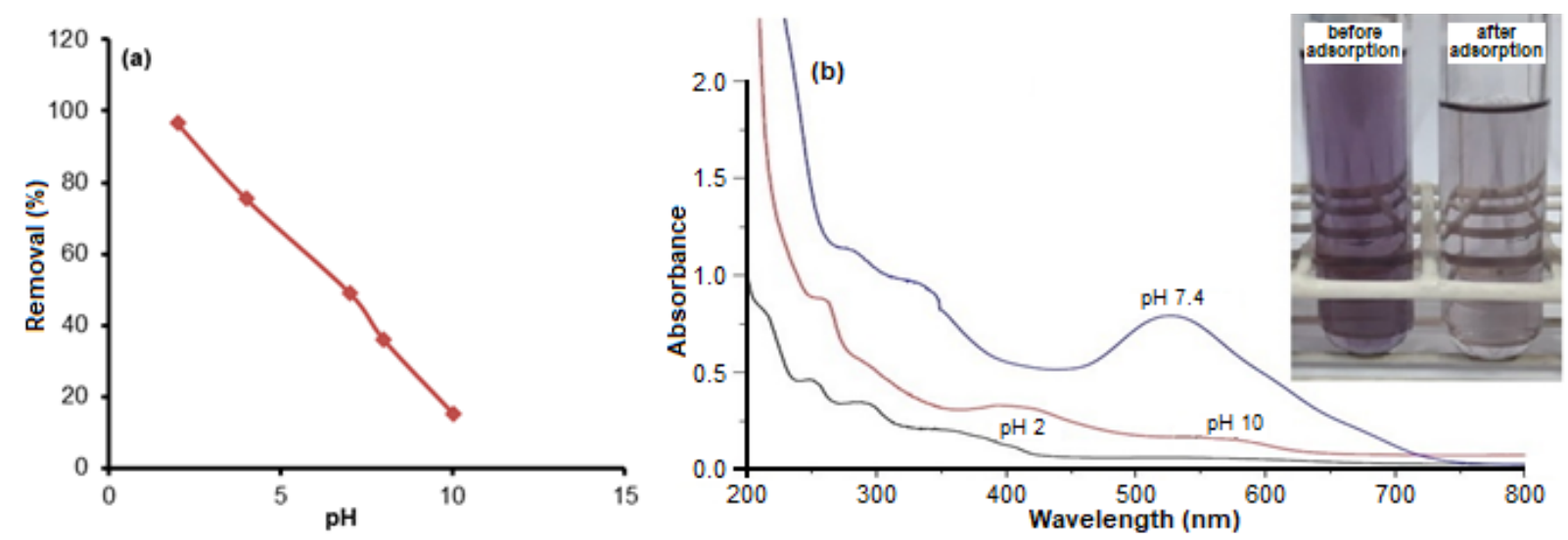

Fig 1. (a) impact of $\mathrm{pH}$ on the adsorption of BET (b) UV-Visible scanning spectrum and BET photographs [at concentration of $50 \mathrm{mg} \mathrm{L}^{-1}$ and $\mathrm{pH}(2,7$, and 10)] of dye before and after adsorption 
Table 3. Values of isotherm variables for sorption EBT on $\mathrm{Co}_{3} \mathrm{O}_{4}$

\begin{tabular}{lllllccc}
\hline Isotherm models & \multicolumn{2}{c}{ Parameter value } & MPSD & EABS & $\mathrm{X}^{2}$ & $\mathrm{X}^{2}$-red & RMSD \\
\hline Langmuir & $\mathrm{K}_{\mathrm{L}}\left(\mathrm{Lmg}^{1}\right)$ & 0.038 & 58.52 & 0.453 & 0.059 & 0.019 & 0.173 \\
& $\mathrm{q}_{\mathrm{e}}\left(\mathrm{mgg}^{-1}\right)$ & 4.3 & & & & & \\
& $\mathrm{R}^{2}$ & 0.99 & & & & & \\
& $\mathrm{R}_{\mathrm{L}}$ & 0.36 & & & & & \\
Freundlich & $\mathrm{K}_{\mathrm{F}}\left(\mathrm{mg} \mathrm{g}^{-1}\right)$ & 3.34 & 231.57 & 0.903 & 3.624 & 1.208 & 0.451 \\
& $1 / \mathrm{n}$ & 0.613 & & & & & \\
\multirow{5}{*}{ Temkin } & $\mathrm{R}^{2}$ & 0.95 & & & & & \\
& $\mathrm{~K}_{\mathrm{T}}(\mathrm{L} / \mathrm{g})$ & 2.31 & 37.443 & 2.083 & 1.351 & 0.450 & 1.041 \\
& $\mathrm{~B}(\mathrm{~J} / \mathrm{mol})$ & 1.07 & & & & & \\
& $\mathrm{~B}(\mathrm{~J} / \mathrm{mol})$ & 2548 & & & & & \\
$\mathrm{D}-\mathrm{R}$ & $\mathrm{R}^{2}$ & 0.95 & & & & & \\
& $\mathrm{q}_{\mathrm{m}}(\mathrm{mg} / \mathrm{g})$ & 2.889 & 493.05 & 8.540 & 388.8 & 129.6 & 2.038 \\
& $\mathrm{~B}\left(\mathrm{~mol}^{2} / \mathrm{kJ} \mathrm{J}^{2}\right)$ & $20^{*} 10^{-5}$ & & & & & \\
& $\mathrm{E}\left(\mathrm{kJ} \mathrm{mol}{ }^{-1}\right)$ & 0.158 & & & & & \\
& $\mathrm{R}^{2}$ & 0.958 & & & & & \\
\hline
\end{tabular}
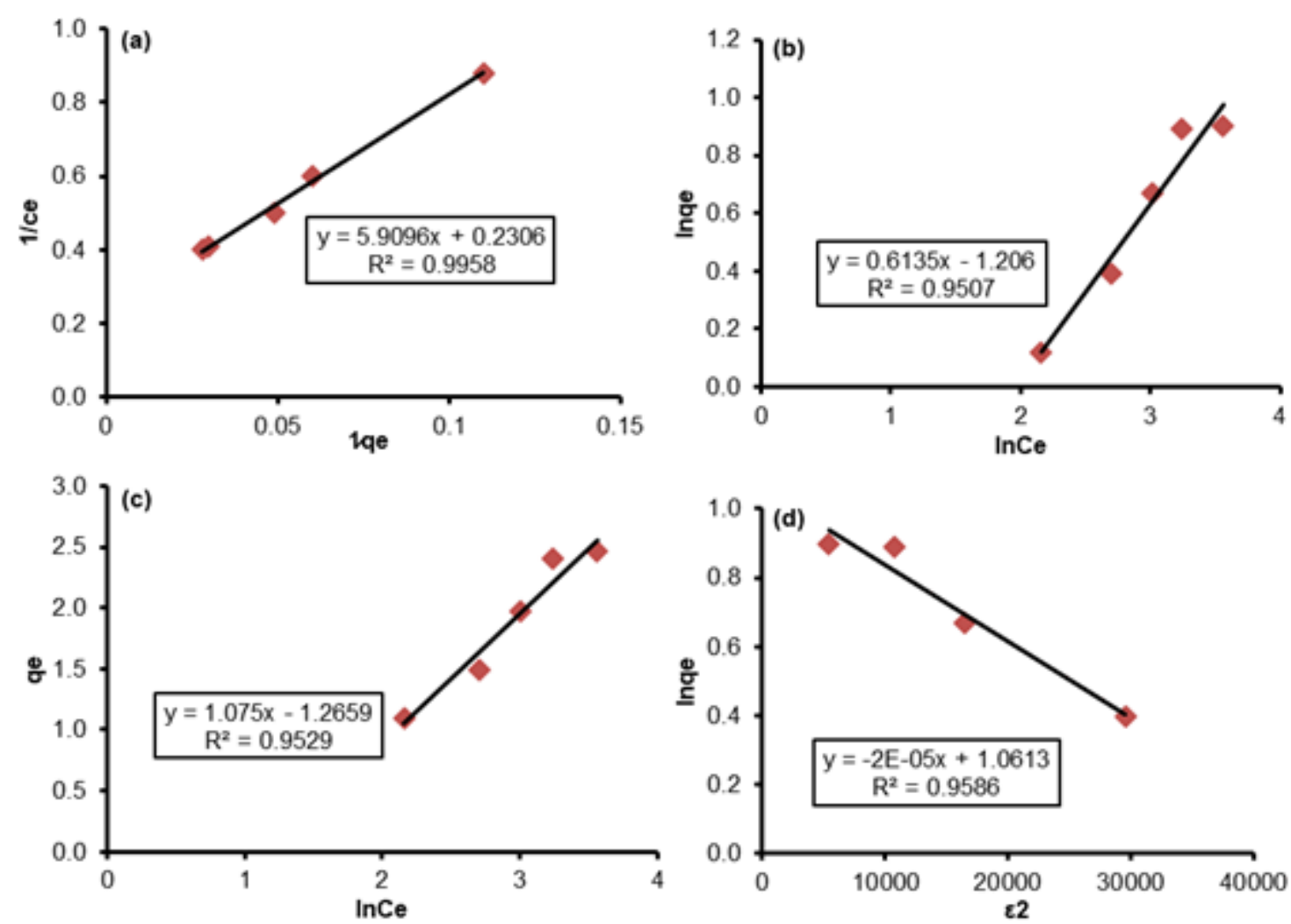

Fig 2. (a) Langmuir, (b) Freundlich, (c) Temkin, and (d) D-H isotherm models at $55^{\circ} \mathrm{C}$

The $\mathrm{K}^{2}$ is a beneficial measurement of the linear or non-linear co-variation of two variables and to derive any inference about the range of the relationship between the Convert empirical data and the expected isotherm [22]. Fig. 3 shows the values of $\mathrm{K}^{2}$ for the isotherms expected by minimizing or maximizing the different error forms for EBT dye. Consequently, RMSD was the preferable error function used to predict the optimum isotherm due to minimal unexplained isotherm, proposing this function as the batter function to reduce the distribution of error 
between the empirical and expected isotherms [30]. Therefore, using RMSD functions, the arrangement for the best isotherm for EBT dye adsorption was as follows: Langmuir $>$ Freundlich $>$ Temkin $>$ D-R.

\section{Effect of Temperature and Thermodynamics Studies}

The effect of temperature is very fundamental in every transfer phenomenon like sorption due to some thermodynamics factor-like enthalpy change $\left(\Delta \mathrm{H}^{\circ}\right)$, entropy change $\left(\Delta S^{\circ}\right)$, and Gibbs free energy change $\left(\Delta G^{\circ}\right)$. The studied thermodynamics factors help us understand the nature of the sorption process, such as endothermic or exothermic [2,31]. So, the adsorption efficiency of EBT on $\mathrm{Co}_{3} \mathrm{O}_{4}$ was found at 45,50 , and $55^{\circ} \mathrm{C}$. Fig. 4 shows the impact of temperature on the adsorption system. It notices that with increasing temperature, the removal efficiency of the EBT dye increases, indicating the endothermic nature of the sorption process. The thermodynamics factor can be defined by the equilibrium constant Kc using the following equations:

$\mathrm{K}_{\mathrm{c}}=\frac{\mathrm{C}_{\mathrm{A}}}{\mathrm{C}_{\mathrm{e}}}$

$\Delta \mathrm{G}^{\circ}=-\mathrm{RT} \ln \left(\mathrm{K}_{\mathrm{c}}\right)$

$\Delta \mathrm{G}^{\circ}=\Delta \mathrm{H}^{\circ}-\mathrm{T} \Delta \mathrm{S}^{\circ}$

$\ln \left(\mathrm{K}_{\mathrm{c}}\right)=\frac{\Delta \mathrm{H}^{\circ}}{\mathrm{RT}}-\frac{\Delta \mathrm{S}^{\circ}}{\mathrm{R}}$

whereas $\mathrm{C}_{\mathrm{A}}$ and $\mathrm{C}_{\mathrm{e}}(\mathrm{g} / \mathrm{L})$ are the concentrations of $\mathrm{EBT}$ in the adsorbent phase and solution at equilibrium. The $\Delta \mathrm{H}^{\circ}$ and $\Delta S^{\circ}$ values determined from the slope and the intercept from the plot of $\ln \mathrm{K}_{\mathrm{c}} \mathrm{vs.} 1 / \mathrm{T}(\mathrm{K}-1)$ [21].

Table 4 showed as a result of thermodynamics factors, where the positive charge of $\Delta \mathrm{H}^{\circ}$ referred that the adsorption nature is endothermic, which is supported by the prediction from the Temkin model and the increase in EBT removal with raising the temperature from $318 \mathrm{~K}$ to $328 \mathrm{~K}[1,28]$. Whereas, the positive values of $\Delta S^{\circ}$ propose a raising the randomness at the solid-liquid interface, which showed that the sorption system is favorable [9]. The $\Delta \mathrm{G}^{\circ}$ values suggest that at low temperatures, the adsorption process is non-spontaneous, while spontaneity happens at high-temperature [32]. The energy of activation $\left(E_{a}\right)$ was determined based on the following relationship:

$\mathrm{E}_{\mathrm{a}}=\Delta \mathrm{H}^{\circ}+\mathrm{RT}$

In this study, the activation energy values (less than $42 \mathrm{~kJ} \mathrm{~mol}^{-1}$ ) indicating the adsorption processes controlled by diffusion [33].

\section{Adsorption Kinetics}

Adsorption kinetics gives more information about the reaction pathways and sorption mechanisms of the

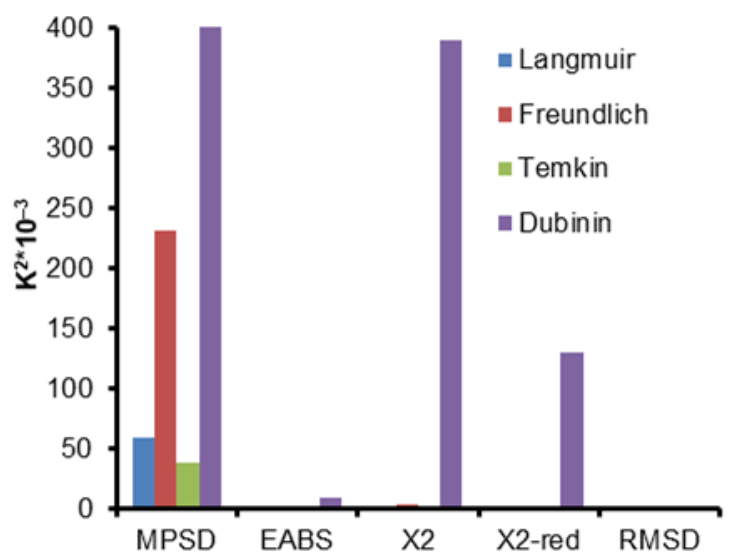

Fig 3. The relationship between Error function and isotherm models of EBT adsorption onto $\mathrm{Co}_{3} \mathrm{O}_{4}$ surface

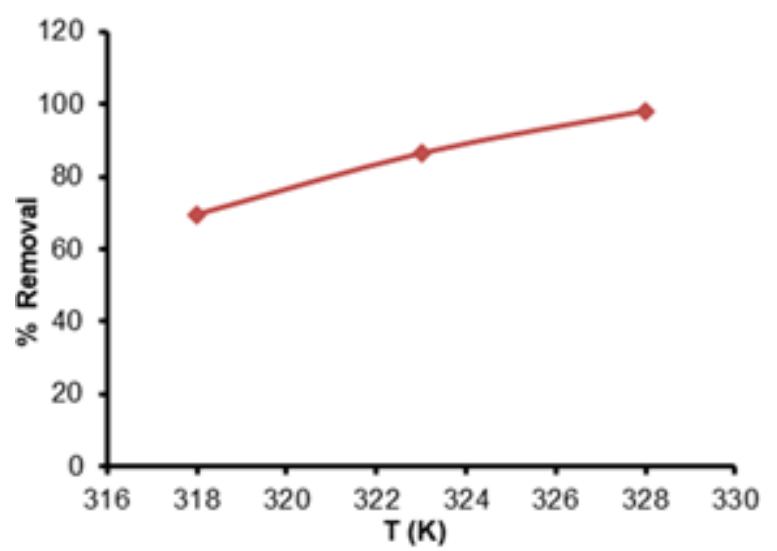

Fig 4. Impact of temperature on the adsorption system

Table 4. Thermodynamics factors of the sorption BET dye on the $\mathrm{Co}_{3} \mathrm{O}_{4}$

\begin{tabular}{ccccc}
\hline $\mathrm{T}(\mathrm{K})$ & $\Delta \mathrm{G}^{\circ} \mathrm{KJ} / \mathrm{mol}$ & $\Delta \mathrm{H}^{\circ} \mathrm{KJ} / \mathrm{mol}$ & $\Delta \mathrm{S}^{\circ} \mathrm{J} / \mathrm{mol}$ & $\mathrm{A} \mathrm{kJ} \mathrm{mol}^{-1}$ \\
\hline 318 & 0.156 & 9.06 & 28.23 & 11.703 \\
323 & -0.058 & & & 11.74 \\
328 & -0.199 & & & 11.786 \\
\hline
\end{tabular}


sorbate by the sorbent and helps understand system dynamics [8]. Two kinetics models were used to explain the kinetics studied of removal EBT dye on $\mathrm{Co}_{3} \mathrm{O}_{4}$ surface by pseudo-first and pseudo-second-order models as shown in Table 5.

Depending on the results from the amounts of $\left(\mathrm{R}^{2}\right)$, error function, and kinetic factors in Table 5, we noticed that the pseudo-second-order was best suited to describe the kinetics of the adsorption. The pseudo-second-order had a higher $\mathrm{R}^{2}(0.990)$ value and a smaller error function for the five models. Furthermore, the calculated $\mathrm{q}_{\mathrm{e}}(\mathrm{cal})$ (0.638) value measured from pseudo-second-order kinetic model was analogous to the empirical $\mathrm{q}_{\mathrm{e}}(\exp )=0.6$ amounts whereas the $\mathrm{q}_{\mathrm{e}}(\mathrm{cal})$ (0.5) for the pseudo-firstorder model was not. These results demonstrate the success of a pseudo-second-degree model in describing EBT dye uptake kinetics [34-35] (Fig. 5). For kinetic studies, RMSD functions are the preferable error function used to predict the kinetic model, as shown in Fig. 6.

\section{Comparison with Other Research}

This report included comparing the results of our study with other reports on the removal of EBT by different adsorbents, as shown in Table 6. As noticed, the

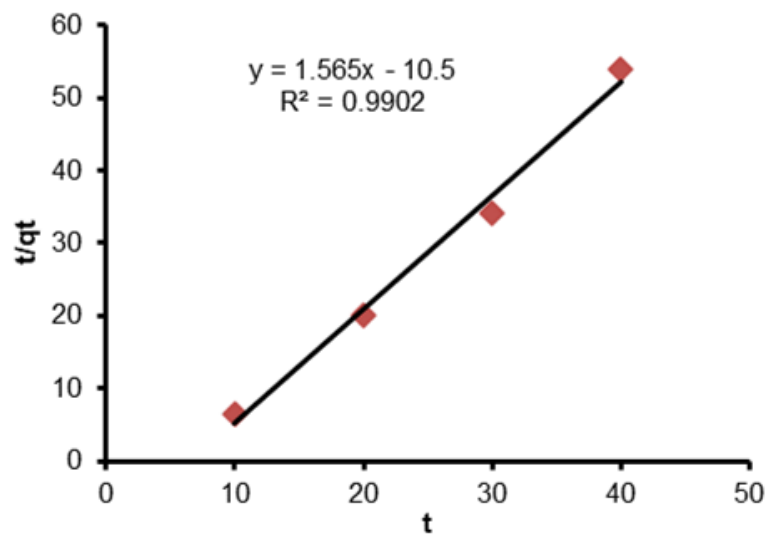

Fig 5. Pseudo-second-order model of EBT sorption

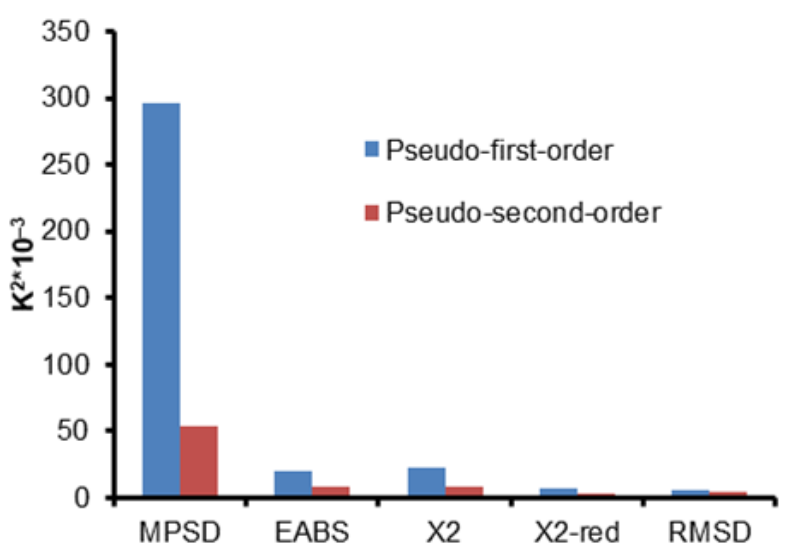

Fig 6. The relationship between Error function and kinetics models of EBT adsorption onto $\mathrm{Co}_{3} \mathrm{O}_{4}$ surface

Table 5. Kinetic parameters for removal of EBT dye

\begin{tabular}{llllllll}
\hline Kinetics models & \multicolumn{2}{c}{ Parameter value } & MPSD & EABS & $\mathrm{X}^{2}$ & $\mathrm{X}^{2}$-red & RMSD \\
\hline Pseudo-first-order & $\mathrm{K}_{1}$ & 0.016 & 295.65 & 19.7 & 22.253 & 7.417 & 6.3553 \\
& $\mathrm{q}_{\mathrm{e}}$ & 0.5 & & & & & \\
& $\mathrm{R}^{2}$ & 0.89 & & & & & \\
Pseudo-second-order & $\mathrm{K}_{2}$ & 0.23 & 53.66 & 8.362 & 7.769 & 2.5896 & 4.1809 \\
& $\mathrm{q}_{\text {e(cal) }}$ & 0.638 & & & & & \\
& $\mathrm{q}_{\text {(eexp }}$ & 0.6 & & & & & \\
& $\mathrm{R}^{2}$ & 0.99 & & & & & \\
\hline
\end{tabular}

Table 6. Comparison results of removal of EBT with other adsorbents in literature

\begin{tabular}{lcccc}
\hline Adsorbent & $\begin{array}{l}\text { Contact time } \\
(\mathrm{min})\end{array}$ & $\begin{array}{l}\mathrm{pH} / \text { adsorption } \\
\text { nature }\end{array}$ & $\begin{array}{l}\text { Removal } \\
\text { percentage \% }\end{array}$ & Ref. \\
\hline Biochar-derived date palm fronds waste & 240 & 2/endothermic & - & {$[36]$} \\
Graphene/NiMgAl-layered hydroxides & 180 & $2 /$ exothermic & - & {$[24]$} \\
Cotton waste & 120 & $2 /-$ & 83.4 & {$[15]$} \\
Activated carbon prepared from waste rice hulls & 60 & $2 /-$ & 93.1 & {$[20]$} \\
$\mathrm{H}_{3} \mathrm{PO}_{4}$-modified berry leaves & 60 & $-/$ exothermic & 91.0 & {$[9]$} \\
Nteje clay & 60 & 2/endothermic & 92.0 & {$[2]$} \\
Surfactant modified clay & 30 & 3/endothermic & 70.0 & {$[8]$} \\
$\mathrm{Co}_{3} \mathrm{O}_{4}$ & 50 & 2/endothermic & 96.6 & This study \\
\hline
\end{tabular}


contact time is lower than other adsorbents (except adsorption of dye in surfactant modified clay surface had lower time). Table 6 shows that $\mathrm{Co}_{3} \mathrm{O}_{4}$ had the best equilibrium time and highest removal percentage showing $\mathrm{Co}_{3} \mathrm{O}_{4}$ as a feasible adsorbent for removing EBT dye from water. The low $\mathrm{pH}$ of EBT absorption is preferred for various absorbents.

\section{- CONCLUSION}

In this report, the sorption of EBT dye from an aqueous solution using low-cost $\mathrm{Co}_{3} \mathrm{O}_{4}$ surface was investigated. EBT adsorption occurred with an equilibrium time of $50 \mathrm{~min}$ and an optimal $\mathrm{pH}$ of 2 , with the removal percentage of adsorption increasing with temperature. According to the isotherm study, the Langmuir isotherm is the appropriate model for the adsorption system, which confirmed the highest $\mathrm{R}^{2}$ value and the smallest value of error functions, indicating that favorable monolayer adsorption was observed between EBT and $\mathrm{Co}_{3} \mathrm{O}_{4}$. The adsorption process was occurred via physical nature and controlled by diffusion. The sorption kinetics followed a pseudo-second-order model with the excellent agreement between experiments and calculated sorption capacity, as well as the highest $\mathrm{R}^{2}$ and the smallest error function values. The adsorption of EBT was endothermic and spontaneous at high temperatures. From the $\mathrm{K}^{2}$ value, the RMSD function was identified as the best function for foretelling the isotherm and kinetic models.

\section{- ACKNOWLEDGMENTS}

We are grateful to Mustansiriyah University, College of Science, and Department of Chemistry for their valuable help.

\section{- REFERENCES}

[1] Barka, N., Abdennouri, M., and EL Makhfouk, M., 2001, Removal of methylene blue and Eriochrome Black $\mathrm{T}$ from aqueous solutions by biosorption on Scolymus hispanicus L.: Kinetics, equilibrium and thermodynamics, J. Taiwan Inst. Chem. Eng., 42 (2), 320-326.

[2] Elijah, O.C., and Joseph, N., 2014, Adsorption studies on the removal of Eriochrome Black-T from aqueous solution using Nteje clay, SOP Trans. Appl. Chem., $1(2), 14-25$.

[3] Ventura-Camargo, B.C., and Marin-Morales, M.A., 2013, Azo dyes: Characterization and toxicity-A review, TLIST, 2 (2), 85-103.

[4] Deb, A., Debnath, A., and Saha, B., 2020, Sonoassisted enhanced adsorption of Eriochrome Black$\mathrm{T}$ dye onto a novel polymeric nanocomposite: Kinetic, isotherm, and response surface methodology optimization, J. Dispersion Sci. Technol., 0 (0), 1-14.

[5] Singh, P.K., and Singh, R.L., 2017, Bio-removal of azo dyes: A review, Int. J. Appl. Sci. Biotechnol., 5 (2), 108-126.

[6] Khurana, I., Shaw, A.K., Bharti, Khurana, J.M., and Rai, P.K., 2018, Batch and dynamic adsorption of Eriochrome Black $\mathrm{T}$ from water on magnetic graphene oxide: Experimental and theoretical studies, J. Environ. Chem. Eng., 6 (1), 468-477.

[7] Dave, P.N., Kaur, S., and Khosla, E., 2011, Removal of Eriochrome Black- $\mathrm{T}$ by adsorption on to eucalyptus bark using green technology, Indian J. Chem. Technol., 18 (1), 53-60.

[8] Zeydouni, G., Kianizadeh, M., Khaniabadi, Y.O., Nourmoradi, H., Esmaeili, S., Mohammadi, M., and Rashidi, R., 2018, Eriochrome black-T removal from aqueous environment by surfactant modified clay: Equilibrium, kinetic, isotherm, and thermodynamic studies, Toxin Rev., 38 (4), 307317.

[9] Ahmaruzzaman, M., Ahmed, M.J.K., and Begum, S., 2015, Remediation of Eriochrome Black Tcontaminated aqueous solutions utilizing $\mathrm{H}_{3} \mathrm{PO}_{4}{ }^{-}$ modified berry leaves as a non-conventional adsorbent, Desalin. Water Treat., 56 (6), 15071519.

[10] Safa, Y., 2014, Biosorption of Eriochrome Black T and Astrazon FGGL blue using almond and cotton seed oil cake biomass in a batch mode, J. Chem. Soc. Pak., 36 (4), 614-623.

[11] Alp, H., Ince, M., Ince, O.K., and Onal, A., 2020, Biosorptive removal of Eriochrome Black-T using Agaricus campestris: Parameters optimization with 
response surface methodology, Desalin. Water Treat., 175, 244-254.

[12] Bansal, M., Patnala, P.K., and Dugmore, T., 2020, Adsorption of Eriochrome Black-T (EBT) using tea waste as a low cost adsorbent by batch studies: A green approach for dye effluent treatments, Curr. Res. Green Sustainable Chem., 3, 100036.

[13] de Luna, M.D.G., Flores, E.D., Genuino, D.A.D., Futalan, C.M., and Wan, M.W., 2013, Adsorption of Eriochrome Black T (EBT) dye using activated carbon prepared from waste rice hullsOptimization, isotherm and kinetic studies, $J$. Taiwan Inst. Chem. Eng., 44 (4), 646-653.

[14] Singh, S.A., Vemparala, B., and Madras, G., 2015, Adsorption kinetics of dyes and their mixtures with $\mathrm{Co}_{3} \mathrm{O}_{4}-\mathrm{ZrO}_{2}$ composites, J. Environ. Chem. Eng., 3 (4, Part A), 2684-2696.

[15] Sivarajasekar, N., and Baskar, R., 2013, Adsorption of basic red 9 onto activated carbon derived from immature cotton seeds: Isotherm studies and error analysis, Desalin. Water Treat., 52 (40-42) 77437765.

[16] Aly-Eldeen, M.A., El-Sayed, A.A.M., Salem, D.M.S.A., and El Zokm, G.M., 2018, The uptake of Eriochrome Black $\mathrm{T}$ dye from aqueous solutions utilizing waste activated sludge: Adsorption process optimization using factorial design, Egypt. J. Aquat. Res., 44 (3), 179-186.

[17] Abbas, R.F., Hami H.K., and Mahdi, N.I., 2019, Removal of doxycycline hyclate by adsorption onto cobalt oxide at three different temperatures: Isotherm, thermodynamic and error analysis, Int. J. Environ. Sci. Technol.,16 (10), 5439-5446.

[18] Prasetyo, I., Mukti, N.I.F., Fahrurrozi, M., and Ariyanto, T., 2018, Removing ethylene by adsorption using cobalt oxide-loaded nanoporous carbon, ASEAN J. Chem. Eng., 18 (1), 9-16.

[19] Abbas, R.F., Hami, H.K., Mahdi, N.I., and Waheb, A.A., 2020, Removal of Eriochrome Black $\mathrm{T}$ dye by using $\mathrm{Al}_{2} \mathrm{O}_{3}$ nanoparticles: Central composite design, isotherm and error analysis, Iran. J. Sci. Technol. Trans. A, 44 (4), 993-1000.
[20] Dada, A.O., Olalekan, A.P., Olatunya, A.M., and Dada, O., 2012, Langmuir, Freundlich, Temkin and Dubinin-Radushkevich isotherms studies of equilibrium sorption of $\mathrm{Zn}^{2+}$ unto phosphoric acid modified rice husk, IOSR J. Appl. Chem., 3 (1), 3845.

[21] Kumar, K.V., Porkodi, K., and Rocha, F., 2008, Isotherms and thermodynamics by linear and nonlinear regression analysis for the sorption of methylene blue onto activated carbon: Comparison of various error functions, J. Hazard. Mater., 151 (2-3), 794-804.

[22] Sivarajasekar, N., and Baskar, R., 2019, Adsorption of Basic Magenta II onto $\mathrm{H}_{2} \mathrm{SO}_{4}$ activated immature Gossypium hirsutum seeds: Kinetics, isotherms, mass transfer, thermodynamics and process design, Arabian J. Chem., 12 (7), 1322-1337.

[23] Kazeem, T.S., Zubair, M., Daud, M., and Al-Harthi, M.A., 2020, Enhanced removal of Eriochrome Black $\mathrm{T}$ using graphene/NiMgAl-layered hydroxides: Isotherm, kinetic, and thermodynamic studies, Arabian J. Sci. Eng., 45 (9), 7175-7189.

[24] Ladhe, U.V., Wankhede, S.K., Patil, V.T., and Patil, P.R., 2011, Removal of Eriochrome Black T from synthetic wastewater by cotton waste, J. Chem., 8 , 178607.

[25] Hami, H.K., Abbas, R.F., Waheb, A.A., and Mahdi, N.I., 2020, Removal of Eriochrome Black T from aqueous solution using $\mathrm{Al}_{2} \mathrm{O}_{3}$ surface: Linear and non-linear isotherm models, error analysis and thermodynamic studies, Mater. Today: Proc., 20, 599-604.

[26] Ahmed, I.A., Al-Radadi, N.S., Hussein, H.S., and Ragab, A.H., 2019, Environmentally friendly mesoporous nanocomposite prepared from aldross waste with remarkable adsorption ability for toxic anionic dye, J. Chem., 2019, 7685204.

[27] Sonba, H.J., and Ridha, S.H., 2014, Thermodynamics of adsorption of Eriochrome Black-T dye from aqueous media on each modified kaolin clay and talc, Acta Chim. Pharm. Indica, 4 (2), 111-118. 
[28] Moeinpour, F., Alimoradi, A., and Kazemi, M., 2014, Efficient removal of Eriochrome black- $\mathrm{T}$ from aqueous solution using $\mathrm{NiFe}_{2} \mathrm{O}_{4}$ magnetic nanoparticles, J. Environ. Health Sci. Eng., 12 (1), 112.

[29] Inam, E., Etim, U.J., Akpabio, E.G., and Umoren, S.A., 2017, Process optimization for the application of carbon from plantain peels in dye abstraction, $J$. Taibah Univ. Sci., 11 (1), 173-185.

[30] Shahmohammadi-Kalalagh, S., and Babazadeh, H., 2014, Isotherms for the sorption of zinc and copper onto kaolinite: Comparison of various error functions, Int. J. Environ. Sci. Technol., 11, 111-118.

[31] Nahali, L., Miyah, Y., Assila, O., El Badraoui, A., ElKhazzan, B., and Zerrouq, F., 2019, Kinetic and thermodynamic study of the adsorption of two dyes: Brilliant green and Eriochrome Black $\mathrm{T}$ using a natural adsorbent "sugarcane bagasse", Moroccan $\mathrm{J}$. Chem., 7 (4), 715-726.

[32] Ogundipe, K.D., and Babarinde, A., 2017, Comparative study on batch equilibrium biosorption of $\mathrm{Cd}(\mathrm{II}), \mathrm{Pb}(\mathrm{II})$ and $\mathrm{Zn}$ (II) using plantain (Musa paradisiaca) flower: Kinetics, isotherm, and thermodynamics, Chem. Int., 3 (2), 135-149.
[33] Saha, T.K., Bishwas, R.K., Karmaker, S., and Islam, Z., 2020, Adsorption characteristics of Allura red AC onto sawdust and hexadecylpyridinium bromide-treated sawdust in aqueous solution, ACS Omega, 5 (22), 13358-13374.

[34] Mustapha, S., Shuaib, D.T., Ndamitso, M.M., Etsuyankpa, M.B., Sumaila, A., Mohammed, U.M., and Nasirudeen, M.B., 2019, Adsorption isotherm, kinetic and thermodynamic studies for the removal of $\mathrm{Pb}(\mathrm{II}), \mathrm{Cd}(\mathrm{II}), \mathrm{Zn}$ (II) and $\mathrm{Cu}(\mathrm{II})$ ions from aqueous solutions using Albizia lebbeck pods, Appl. Water Sci., 9 (6), 142.

[35] Hami, H.K., Abbas, R.F., and Jasim, A.A., 2019, Kinetics study of removal doxycycline drug from aqueous solution using aluminum oxide surface, Egypt. J. Chem., 62, 91-101.

[36] Zubair, M., Mu'azu, N.D., Jarrah, N., Blaisi, N.I., Abdul Aziz, H., and Al-Harthi, M.A., 2020, Adsorption behavior and mechanism of methylene blue, crystal violet, Eriochrome Black T, and methyl orange dyes onto biochar-derived date palm fronds waste produced at different pyrolysis conditions, Water, Air, Soil Pollut., 231 (5), 240. 